\title{
Growing Teratoma Syndrome: A case report
}

\author{
Nadir Bir Teratom Komplikasyonu, Büyüyen Teratom Sendromu
}

\author{
Elif Sitre Koc ${ }^{*}$, Oyku Beyaz
}

Acıbadem Mebmet Ali Aydinlar University School of Medicine, Department of Internal Medicine, Istanbul,Türkiye.

\begin{abstract}
Seminomas and non-seminomatous germ cell tumors of the testis are the most common solid neoplasms in young men. There are rare cases where seminomas and non-seminomatous tumors cells are seen together. Non-seminomatous germ cell tumors which have generally good prognosis may feature with growing masses, despite chemotherapy and consequent diminishing or normal tumor markers. These cases are called Growing Teratoma Syndrome (GTS). Growing Teratoma Syndrome is diagnosed with: (i) normalization of tumor markers (AFP and / or hCG) that have been elevated before chemotherapy, (ii) increased tumor volume during or after chemotherapy, and (iii) biopsy result consistent with mature teratoma. In the management of GTS, the early and complete surgical removal of the tumor constitutes the main approach. With early diagnosis and correct intervention GTS cases have very good prognosis. Herein, we report a patient diagnosed with GTS after two courses of chemotherapy.

Key Words: Teratoma; Chemotherapy; Biomarkers; Tumor; Germ Cells
\end{abstract}

\section{Objective}

Germ cell tumors of the testis are the most common solid neoplasms in young men (1). These tumors are classified as seminomas and nonseminomatous germ cell tumors (NSGCT). There are rare cases where seminoma and nonseminomatous cells are seen together. These are also included in the NSGCT classification (2). Non-seminomatous germ cell tumors generally have good prognosis. However, occasionally, they may feature with growing masses, despite chemotherapy and consequent diminishing or normal tumor markers. These cases are called Growing Teratoma Syndrome (GTS). Growing Teratoma Syndrome, which was first defined by

\begin{abstract}
Özet
Seminom ve non-seminomatoz germ hücreli tümörlerin oluşturduğu testis tümörleri genç erkeklerde en sık rastlanan solid neoplazmlardır. Seminom ve non-seminomatoz tümörlerin birlikte görüldüğü nadir durumlar da vardır. Genellikle iyi prognoza sahip olan non-seminomatoz germ hücreli tümörler kemoterapiye ve normale dönen tümör belirteçlerine rağmen büyüyen kitleler şeklinde ortaya çıkabilir. Bu vakalara Büyüyen Teratom Sendromu (BTS) denir. Büyüyen Teratom Sendromu kriterleri şunlardır: (i) kemoterapiden önce artmış tümör belirteçlerinin (AFP ve/veya hCG) normalleşmesi, (ii) kemoterapi sırasında veya sonrasında tümör büyüklüğ̈nün artmas1 ve (iii) mature teratomla uyumlu biyopsi sonucu. BTS tedavisinde esas yaklaşım, tümörün erken tanısı ve cerrahi olarak çıkarılmasıdır. Erken tanı ve doğru müdahale ile BTS vakalarının prognozu çok iyidir. Burada, iki kür kemoterapiden sonra BTS tanısı konan bir hastayı sunuyoruz.
\end{abstract}

Anahtar Kelimeler: Biyobelirteçler; teratom; Tümörler, germ hücre ve embriyonel

Logothesis in 1982, is seen in $2-7 \%$ of NSGCT. Growing Teratoma Syndrome is diagnosed with: (i) normalization of tumor markers (AFP and / or hCG) that have been elevated before chemotherapy, (ii) increased tumor volume during or after chemotherapy, and (iii) biopsy result consistent with mature teratoma (3, 4). Unlike NSGCT, which is sensitive to chemotherapy, GTS is resistant to both chemotherapy and radiotherapy. Therefore, in the management of GTS, the early and complete surgical removal of the tumor constitutes the main approach. With early diagnosis and correct intervention GTS cases have a very good prognosis. 


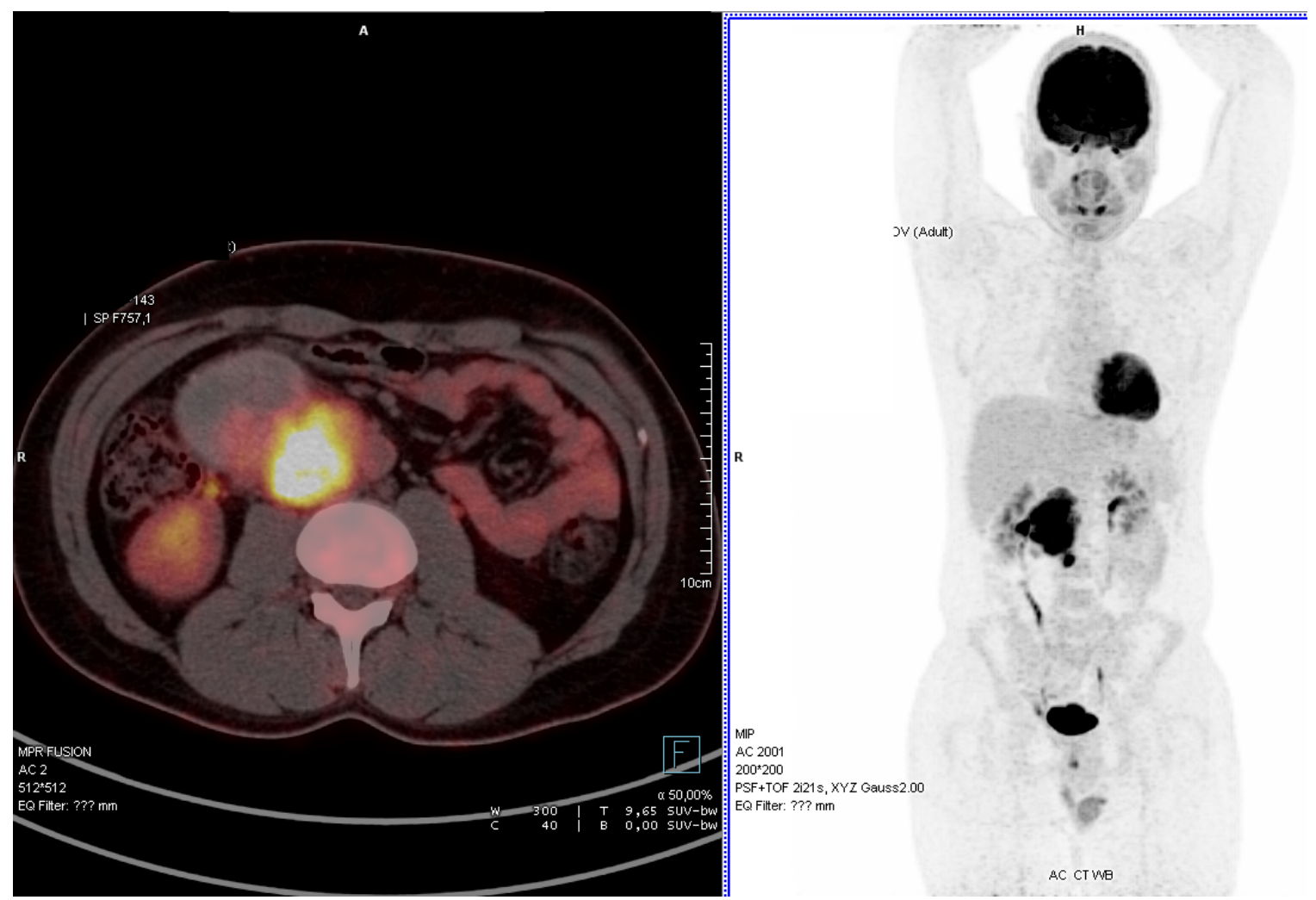

Fig.1.Conglomerated lymph nodes and concomitant non-metabolic hyperdense components in abdominal region

\section{Case Report}

A 34-year-old pilot presented to our clinic for routine airline health screening. On urological review, he complained of pain during urination and right testicular pain. Physical examination revealed a partially mobile, palpable mass in the right upper abdomen. Hemogram, renal function tests, liver function tests, electrolytes and urinalysis were all within normal limits. Urinary system ultrasonography (US) showed no significant renal or bladder abnormality, whereas in scrotal color doppler US, revealed a heterogeneous acoustic shadow consistent with malignancy in the right testis. There was also micro-lithiasis in the right testis and grade II varicocele in the left testis. Related tumor markers were studied and while AFP level was in normal range, $\mathrm{LDH}$ and $\mathrm{B}-\mathrm{hCG}$ levels were found to be high: $\mathrm{AFP}=3.7 \mathrm{IU} / \mathrm{mL}$ (normal range: 0-6.7 $\mathrm{IU} / \mathrm{mL}$ ), $\mathrm{LDH}=407 \mathrm{IU} / \mathrm{L}$ (normal range: 85-227), $\mathrm{B}-\mathrm{hCG}=6.5 \mathrm{mIU} / \mathrm{ml}$ (normal range: 0- 2.6 $\mathrm{mIU} / \mathrm{mL}$ ). Computed tomography (CT) of the thorax showed two lymph nodes which were primarily suggestive of neoplastic disorders of $9 \times 7$ $\mathrm{cm}$ and $8 \times 7 \mathrm{~cm}$ in size located in the aortacaval region. Abdominal CT revealed a few pathological-looking conglomerated lymph nodes of $7.5 \times 6.5 \times 8 \mathrm{~cm}$ in diameter within the interaortacaval and paracaval lenfatik chains that displaced vena cava inferior, duodenum, and the head of pancreas towards anterior. A right orchiectomy was performed. Histopathological examination revealed a mixed germ cell tumor (seminoma 20\%, mature teratoma $80 \%$ ) which was $25 \mathrm{~mm}$ in diameter and limited to the testis without any sign of necrosis or invasion. Pathological staging of the tumor was done as pT1acN3MxS1. PET-CT examination showed conglomerated lymph nodes and concomitant non-metabolic hyperdense components of $6.5 \times 5.5$ $\mathrm{cm}$ in abdominal region consistent with metastasis of the primary pathology (Figure1). Adjuvant chemotherapy with three courses of BEP (Bleomycin, Etoposide, Cisplatin) was planned. Throughout the chemotherapy, patient was closely monitored in clinical and laboratory aspects.Levels of tumor markers following the first course of chemotherapy were as follows: $\mathrm{AFP}=5.9 \mathrm{IU} / \mathrm{mL}$ (normal range: 0-6.7 IU/mL), $\mathrm{LDH}=1266 \mathrm{IU} / \mathrm{L}$ (normal range: 85-227), B-hCG $<2.0 \mathrm{mIU} / \mathrm{ml}$ (normal range: $0-2.6 \mathrm{mIU} / \mathrm{mL}$ ). Following the second course of chemotherapy, the patient complained of abdominal pain upon which an 
abdominal US was performed, and it was observed that the conglomerated lymph no previously measured as $6 \times 7.5 \mathrm{~cm}$ in abdominal CT were regressed to $3.3 \times 2.5 \mathrm{~cm}$ while lesion size was measured as $7.5 \times 6.5 \mathrm{~cm}$ and detected larger than previous scan. At the same time, tumor markers were found as follows: $\mathrm{AFP}=5.9 \mathrm{IU} / \mathrm{mL}$ (normal range: 0-6.7 $\mathrm{IU} / \mathrm{mL}$ ), $\mathrm{LDH}=224 \mathrm{IU} / \mathrm{L}$ (normal range: $85-227$ ), $\mathrm{B}-\mathrm{hCG}<2.0 \mathrm{mIU} / \mathrm{ml}$ (normal range: $0-2.6 \mathrm{mIU} / \mathrm{mL}$ ). Due to normal values of tumor markers and characteristics of imaging the case was considered as GTS. Total removal of the mass located in the abdomen with a size of $7.5 \times 6.5 \mathrm{~cm}$ was performed surgically Pathological examination was consistent with mature teratoma which did not show invasion and the diagnosis of GTS was confirmed. The patient was discharged as a cure and no recurrence was observed after 2 months of follow-up.

\section{Discussion}

In this report, we presented a case with all the characteristics of the GTS, whose informed consent was obtained during the patient's stay in hospital. This rare condition manifests itself as growing masses despite appropriate chemotherapy and consequent decreasing or normal tumor markers (4). The diagnosis is confirmed by observation of mature teratoma and the absence of malignant germ cells in pathological examination. Growing Teratoma Syndrome occurs in $2-7 \%$ of NSGCT cases (3). Although the etiology is not exactly known, a few hypotheses have been introduced. The most commonly accepted hypothesis by Andre et al. suggests that chemotherapy is effective on immature malignant cells and prolongs the duration of the disease and allows more growth of benign cells $(5,6)$. Growing teratoma syndrome may develop any time after chemotherapy. In the literature, there were cases seen immediately after two courses of chemotherapy as well as those seen 12 years after the end of chemotherapy (7). In our case, findings suggesting GTS were seen after two courses of chemotherapy. As in our case, the mass shows mostly retroperitoneal involvement in the GTS cases. Other places where the tumor was shown include; lung, mediastinum, lymph nodes, mesentery, and liver (8). Although the tumor in the GTS cases is of benign origin, the mass has the potential to damage the surrounding vital structures because of its very rapid growth. The organs to which the tumor mass can damage depends on its localization, thus, there is a need for a multidisciplinary approach in the planning and implementation of the treatment. Radical surgery is the gold standard in the treatment of GTS. With complete resection of the tumor, the rate of recurrence is $0-4 \%$, and this rate rises to $72-83 \%$ with incomplete surgery (9). In our report, the patient had normal clinical and laboratory signs and no complaints on his returns for routine follow-ups after chemotherapy cessation and surgery. In the management of GTS, it is aimed to remove the tumor early and fully by surgical intervention. Growing Teratoma Syndrome cases with early diagnosis and correct intervention demonstrate a very good prognosis. In this case report, we aimed to raise awareness of a rare condition called GTS, keeping in mind the rare syndromes will lead the clinician to right diagnosis and treatment method.

Conflict of Interests: The authors have no conflict of interest.

\section{References}

1. Albers P, Albrecht W, Algaba F, Bokemeyer C, Cohn-Cedermark G, Fizazi $\mathrm{K}$, et al. Guidelines on Testicular Cancer: 2015 Update. Eur Urol 2015; 68(6): 10541068

2. Moch H, Cubilla AL, Humphrey PA, Reuter VE, Ulbright TM. The 2016 WHO Classification of Tumours of the Urinary System and Male Genital Organs-Part A: Renal, Penile, and Testicular Tumours. Eur Urol 2016; 70(1): 93-105.

3. Michalski W, Jonska-Gmyrek J, Poniatowska G, Kucharz J, Stelmaslak P, Nietupski $K$, et al. Testicular teratomas: a growing problem? Med Oncol 2018; 35(12): 153.

4. Paffenholz P, Pfister D, Matveev V, Heidenreich A. Diagnosis and management of the growing teratoma syndrome: A single-center experience and review of the literature. Urol Oncol 2018; 36(12): 529.

5. Nimkin Katherine, Gupta Punita, Mccauley Roy, Gilchrist BF, Lessin MS. The growing teratoma syndrome. Pediatr Radiol 2004; 34(3): 259-262.

6. Andre F, Fizazi K, Culine S, Droz J, Taupin P, Lhomme C, et al. The Growing teratoma syndrome: results of therapy and long-term follow-up of 33 patients. Eur J Cancer 2000; 36(11): 1389-1394.

7. Kataria SP, Varshney AN, Nagar M, Mandal AK, Jha V. Growing teratoma syndrome. Indian J Surg Oncol 2017; 8(1): 46-50. 
Koç and Beyaz. / Growing Teratoma Syndrome: A Case Report

8. Maroto P, Tabernero JM, Villavicencio $H$, Mesla R, Marcuello E, Sole-Balcells, et al. Growing teratoma syndrome: experience of a single institution. Eur Urol 1997;32(3): 305-09.
9. Panda A, Kandasamy D, Sh C, Jana M. Growing Teratoma Syndrome of ovary: avoiding a misdiagnosis of tumour recurrence. J Clin Diagn Res 2014;8(1):197-198. 